\title{
PARANOJA KRYTYCZNA. \\ O ANTROPOLOGICZNYCH \\ BADANIACH KULTURY WŁASNEJ
}

Xawery Stańczyk

Uniwersytet Warszawski

Zmiany paradygmatów i ich wielość, kolejne zwroty i przewroty, zmagania z konkurencyjnymi dyscyplinami $\mathrm{w}$ polu nauk społecznych - to wszystko nie ominęło antropologii kulturowej. Nauka, kiełkująca w czasach dominacji intelektualnej ewolucjonizmu, wciąż nie potrafi sobie poradzić z tym wieloznacznym dziedzictwem, a wystapienia Jamesa Clifforda, George'a E. Marcusa czy Paula Rabinowa bynajmniej nie dały odpowiedzi, jak wyjść z kryzysu, choć odpowiedź tę w jakiś sposób przybliżyły. Wydaje się, że najbardziej podstawowa, konstytutywna wartość antropologii przetrwała, a etyczne, epistemologiczne i instytucjonalne trudności tylko uwydatniły jej fundamentalne znaczenie. Tą wartością jest spotkanie z Innym. Andrzej Mencwel, pisząc na temat wyobraźni antropologicznej, przywołał dwie postacie: Jana Jakuba Rousseau i Claude’a Lévi-Straussa (Mencwel 2006: 10). Rousseau, na sto lat przed powstaniem nowej dyscypliny naukowej, stworzył jej manifest, pisząc o filozofii, która udała się w podróż, a jej celem jest poznanie siebie przez poznanie cudzoziemców. Drugi z wielkich Francuzów rozwinął tę myśl na gruncie swojego szczególnego, strukturalistycznego uniwersalizmu. Antropologia kultury jest więc i pozostanie dążeniem do poznania nie dzięki introspekcji lub medytacji, lecz przez rozpoznanie siebie w Innym, a Innego w sobie. Ten kierunek został ugruntowany $\mathrm{w}$ tradycji wielkich podróży antropologicznych, będących zarazem mitem założycielskim ambitnej dyscypliny.

Wraz z rozwojem antropologii, jak już ogólnikowo zaznaczyłem, kierunek ten rodził coraz więcej pytań i wątpliwości, których punkt kulminacyjny przypadł na lata siedemdziesiąte i osiemdziesiąte. Problemom tym nie poświęcam więcej miejsca, ponieważ są to sprawy znane; znakomicie prześledził je i zanalizował James Clifford w Klopotach z kultura (Clifford 
2000). W książce tej, wobec trudności piętrzących się przed badaczem próbującym nawiązać etyczną i jednocześnie naukową relację z Innym, Clifford rozważa między innymi rezygnację $\mathrm{z}$ dalszego podejmowania prób, które dotychczas kończyły się niekoniecznie szczęśliwie dla obu stron. Sytuacja, w której sami miejscowi badają i interpretuja swoje kultury, zaopatrzywszy się uprzednio w etnograficzny warsztat $\mathrm{i}$ adekwatny korpus wiedzy akademickiej - co zresztą wraz z reaktualizacją tożsamości plemiennych działo się na oczach autora - dawała nadzieję na wyjście z impasu. Clifford taką opcję dopuszczał, upatrywał w niej jednej z szans na przecięcie, a przynajmniej odsunięcie węzła gordyjskiego kolonialnego uwikłania antropologii.

Jak w baśni, w której odrąbanie jednej głowy smoka skutkuje wyrośnięciem kilku następnych, tak w historii antropologii zamiary odejścia od wielkich podróży i konfrontacji z radykalną innością zaowocowały nowymi problemami poznawczymi. Dyskusyjne stało się, jak blisko może antropolog znajdować się wobec kultury, którą bada. Czy można prowadzić badania antropologiczne antropologów we własnej instytucji? Czy obiektem badań może być rodzina lub sąsiedzi antropologa? Oczywiście tak, ponieważ nie chodzi tu o odległość przestrzenną lub czasową, lecz o dystans obiektywizujący, wedle określenia Pierre’a Bourdieu, czyli dystans, który - czego potwierdzeniem jest praktyka naukowa i społeczna samego Bourdieu - nie neguje etycznego i politycznego zaangażowania, natomiast pozwala uniknąć błędu uprzedmiotowienia badanych przez nie dość autokrytyczna próbę ich upodmiotowienia. W artykule tym chcę się skoncentrować na zagadnieniach związanych $\mathrm{z}$ badaniem kultury własnej na przykładzie kultury alternatywnej, ponieważ mi osobiście właśnie ona jest bliska. Zogniskowanie na konkretnej formacji kulturowej uważam za konieczne, gdyż specyfika każdej kultury i stosunek danego badacza do niej wiąża się z odrębnymi, konkretnymi uwarunkowaniami procesu badawczego. Rozważania abstrakcyjne, kuszące ze względu na ich formalną elegancję, mogłyby okazać się niemożliwe do zaaplikowania w rzeczywistych sytuacjach. Dopiero w podsumowaniu podejmę na nowo wątki bardziej ogólne, dotyczące badania kultury własnej.

Problemy z kulturą alternatywną zaczynają się już od kwestii terminologicznych: alternatywna, spontaniczna, oddolna, młodzieżowa, niezależna, a może kontrkultura lub subkultura? Rozróżnienia między tymi kategoriami nie są jasne, często pisze się zamiennie o kontrkulturze lub kulturze alternatywnej, czasem stosuje się więcej niż jeden epitet: spontaniczna kultura młodzieżowa, alternatywna kultura młodzieżowa i tak dalej. A mamy jeszcze takie pojęcia, jak underground, off, trzeci obieg, ruch młodzieżowy, 
ruch alternatywny... Co gorsza, każde z tych pojęć często ma więcej niż jedno znaczenie. Wynika to, po pierwsze, z płynnego, efemerycznego i wielobarwnego zjawiska albo zestawu zjawisk, które miałyby być desygnatem tych terminów. Drugą przyczyną zamieszania jest różnorodność dyskursów, które kultury, powiedzmy, alternatywnej, dotyczą. Odrębne perspektywy maja w danym temacie antropologia kultury, socjologia, pedagogika, historia sztuki, literaturoznawstwo, filmoznawstwo, teatrologia. Kultura alternatywna, włączana niekiedy w szerszy, choć równie niejasny obszar kultury niezależnej, stanowi też przedmiot walk ideologicznych i polityk historycznych. Sami uczestnicy tej kultury także nie ułatwiają zadania, starając się uniknać dyskursywnego przyszpilenia i naukowych kategoryzacji swojej aktywności.

Spróbujmy uporządkować trochę tę wielopłaszczyznową i pełną zaskakujących powiązań, rozgałęzień i przeskoków materię. Samo pojęcie trzeciego obiegu zaistniało właściwie równolegle ze swoim desygnatem. Już w roku 1985 pisał o nim Rafał Jesswein w trzecim numerze „Odry”, utożsamiając trzeci obieg z subkulturą punk. Punkowy rodowód tego pojęcia potwierdza w wypowiedzi cytowanej w albumie Jarocin w obiektymie bezpieki muzyk zespołu Dezerter, Krzysztof Grabowski, zaznaczając dystynkcję wobec opozycji politycznej:

To w końcu byli politycy, którzy jeden system chcieli zastapić innym. Za mało w tym było prawdziwej wolności. Poza tym - nie oszukujmy się - ta najbardziej znana opozycja wywodziła się z PZPR lub przynajmniej miała z nią kontakt. Dopiero w tamtym czasie zmienili zdanie i chcieli coś reformować, a naszym zdaniem tego się reformować nie dało. Niemniej ufaliśmy, że coś dobrego może z tego wyniknąć. Najbardziej podobała się nam sama destrukcja tamtego systemu. Nasze środowisko określaliśmy najczęściej jako trzecią drogę albo trzeci obieg. Nie było to jednak w żaden sposób sformalizowane, bo cały ten ruch nie dał się zamknąć w żadne ramy. (Lesiakowski, Perzyna, Toborek 2004: 58-59)

Socjologiczne badania kultur alternatywnych stały się częstą praktyką w latach osiemdziesiatych, ich metodologia była jednak dopiero w powijakach, a obiekt badań pozostawał mglisty. W „Kulturze Niezależnej” z 1988 roku, w relacji z konferencji Alternatywne wzory kulturowe w Polsce i ich spotecæne znaczenie z 1987 roku, czytamy, że już wtedy: „Sesje na temat alternatywności - już to wariantów kultury, już to stylów życia - mają swój ustalony rytuał. Zaczyna się zawsze od mordobicia o znaczenie pojęcia «alternatywność»» (PE 1988: 84). 
Jednym z pierwszych badaczy, którzy próbowali sformułować koncepcję trzech obiegów, był Jerzy Wertenstein-Żuławski. Kategorię obiegu wprowadził do polskiej humanistyki Stefan Żółkiewski, wyróżniając na materiale empirycznym (w książce Kultura literacka 1918-1932 z roku 1973) i w sposób teoretyczny (w książce Wiedza o kulturze literackiej z 1980 roku) społeczne obiegi literatury. Różne rodzaje literatury krażą w różnych obiegach: każdy z nich ma swoja specyficzną publiczność, z jej nawykami, przyzwyczajeniami, horyzontem oczekiwań. Obiegi więc mogą na siebie zachodzić, przecinać się, a dzieła - przedostawać się z jednego obiegu do drugiego. Pojęcie obiegu nabrało w kulturze polskiej nowego znaczenia po 1976 roku, gdy jawnie zaczęła działać opozycja polityczna, a częścia jej aktywności był od początku nieoficjalny, niepodlegający cenzurze obieg książek, czasopism i ulotek. Zyskał on szybko miano drugiego obiegu, w odróżnieniu od pierwszego - oficjalnego, koncesjonowanego przez państwo, cenzurowanego. Trzeci obieg powstał właściwie w tym samym czasie lub niewiele później, na przełomie lat siedemdziesiątych i osiemdziesiątych, w alternatywnych kręgach kultury młodzieżowej. Wertenstein-Żuławski podjął temat trzech obiegów w 1990 roku, w wystapieniu Trąy obiegi - tray kultury. Struktura społeczna i komunikowanie w dzisiejszej Polsce, podczas VIII Ogólnopolskiego Zjazdu Socjologicznego w Toruniu. Socjolog opisał trzy obiegi kultury zasadniczo w podobny sposób do zaproponowanego powyżej. Przypominał o kontroli i cenzurze, jakim podlegał pierwszy obieg, a także o mass mediach, z których korzystał. Drugi obieg, określany przez socjologa jako opozycyjny, koncentrował się na kwestiach społecznych, politycznych i kulturalnych, przy czym część z wydawanych w nim pism miała charakter konserwatywno-narodowy, a część - awangardowy i ponadnarodowy. Wreszcie trzeci obieg nazywany jest tutaj alternatywnym i młodzieżowym, przeciwstawnym wobec obu pozostałych i skoncentrowanym na krytyce systemu społeczno-kulturowego raczej niż politycznego (Wertenstein-Żuławski 1991: 225-226).

W dalszej części tekstu Wertenstein-Żuławski zestawia trzy obiegi z trzema typami wzorów kulturowych, obecnymi w ówczesnym polskim społeczeństwie. Pierwszy to establishment kulturowy: płynny, zmienny i zróżnicowany, mieszczący się jednak w ramach kultury dominującej. Drugi typ to obszar wykluczenia kulturowego, który wprawdzie nie akceptuje panującego wzoru, lecz nie potrafi skonstruować wobec niego żadnych kontrpropozycji. Ostatnim typem jest kultura spontaniczna i alternatywna, świadcząca o alienacji młodych ludzi (i szybko rosnącym oddaleniu od świata dorosłych, tak w kulturze oficjalnej, jak i w opozycji), ale oferująca 
też własne, innowacyjne modele, instytucje, wartości (tamże: 227). To w tym wzorze kultury były poruszane problemy i idee odrzucane lub lekceważone przez dorosłych i struktury państwowe. Podejmowano je z bardzo różnych perspektyw, za pomocą najróżniejszych środków i technik ekspresji:

Ruchy polityczne, pacyfistyczne, teatry otwarte, eksperymentujące ruchy kulturowe, oazy, wspólnoty religii wschodnich, subkultury zwiazane z muzyką rockowa, niezależne ruchy ekologiczne, a nawet Pomarańczowa Alternatywa zdawały się być - i do pewnego stopnia rzeczywiście były - połączone wspólnotą sprzeciwu wobec narzuconego porządku i podobnym brakiem akceptacji ze strony organów kontroli państwowej. (tamże: 228)

Trzeci typ kultury swoją dynamiczną innością raził większość społeczną, ponieważ to właśnie w nim dokonywano eksperymentów społecznych i kulturowych, starając się odkryć nowe formy relacji, interakcji, współżycia, dotrzeć do prawdy o człowieku, odnaleźć jego właściwe miejsce wśród innych istot (mniejsza w tej chwili o rzetelność i trafność tych eksperymentów). Jedna z cech zasadniczych tego typu kultury była dezautomatyzacja postrzegania świata społecznego. W ujęciu Wertensteina-Żuławskiego trzeci obieg wiąże się właśnie z tym różnorodnym i migotliwym wzorem kulturowym: kultura alternatywną, czymś więcej niż podległa gettoizacji subkultura, czymś więcej niż oparta na całościowej negacji kontrkultura. To powiązanie obiegu i wzoru uważam za niezwykle ważne i - nie podejmując dalej koncepcji tego autora - kluczowe dla następnych rozważań. Oczywiście będzie to wymagało zmiany punktu widzenia, ponieważ Wertenstein-Żuławski kładzie nacisk na cechy negatywne (sprzeciw i odrzucenie) alternatywnego wzoru kultury; brakuje refleksji nad jego wewnętrzną konfiguracją.

Innym socjologiem, podejmującym temat obiegów kultury w zasadzie w tym samym czasie co Wertenstein-Żuławski, był Mirosław Pęczak. W swoim Malym stowniku subkultur młodzieżonych wskazuje on, że podstawowa funkcja terminu „trzeci obieg” było odróżnienie od drugiego obiegu, choć działały one w tych samych, pozainstytucjonalnych i nielegalnych warunkach. Zatem znowu mamy do czynienia z wysuwaniem na pierwszy plan aspektu negatywnego. Dalej Pęczak proponuje definicję enumeratywna, stwierdzając, że do trzeciego obiegu:

zalicza się gazetki (fanziny), kasety z muzyką produkowaną metodą „chałupniczą" (rodzimy ,garażowy rock”), graffiti, a także produkty mail artu. Charakterystyczne cechy trzeciego obiegu to: niewielki zasięg, 
ograniczony do środowisk alternatywnych, wymienność ról nadawcy i odbiorcy, negatywny stosunek do kultury oficjalnej, niechęć do polityki i polityków, maksymalizm aksjologiczny (wartości trzeba realizować w życiu, a nie tylko deklarować). (Pęczak 1992: 96-97)

Pęczak uzupełnia te informacje przybliżonym czasem funkcjonowania trzeciego obiegu mniej więcej w latach 1980-1989, po którym obieg wprawdzie dalej działa (częściowo ulegając instytucjonalizacji), ale z powodu zaniku drugiego obiegu właściwsze byłoby nazywanie go po prostu alternatywnym. Ten badacz zresztą w ogóle uważa kategorie obiegów za nieadekwatne i niewystarczające jako narzędzia opisu.

Galimatias pojęciowy prowadzi nieraz do rezygnacji z jednoznacznego określenia przedmiotu badań. Przykładowo Jan Bińczycki tak uzasadniał niekonsekwencje w swoim artykule:

Underground, alternatywa, off, kontr- i subkultury pojawiaja się tu zamiennie. Nie istnieja precyzyjne, słownikowe definicje tych pojęć. To dobrze, bo tekst na taki temat powinien być jak najmniej akademicki. (Bińczycki 2010: 10)

To optymistyczne przyjęcie niekonsekwentnego opisu oraz zakresu badanych zjawisk poparte jest niewattpliwie wrażliwością wobec obiektu dociekań, którego nie chce się ramować zewnętrznymi, nieprzystającymi do niego kategoriami, niemniej wydaje się jedynie przesłaniające problem, a nie rozwiązujące go. Swoimi praktykami twórcy kultury alternatywnej sami, często świadomie i z premedytacją, sieją pojęciowy zamęt, wymykając się akademickim definicjom, typologiom i klasyfikacjom. Prawdą jest, że bezsensowne i beznadziejne byłoby przykrajanie tych działań do eleganckich i abstrakcyjnych schematów i taksonomii układanych w zaciszu gabinetów przez uczonych. Jednak przyjęcie języka badanych, rezygnacja z własnej pracy analitycznej i systematyzacji niepokornej materii, nawet jeśli upodmiotawia $\mathrm{w}$ jakimś stopniu (bo ostatecznie pisze zawsze badacz) przedmiot dociekań, to nie ułatwia jego zrozumienia. Tego typu bezradność nie jest wszak nie do uniknięcia. Wyjaśniając swoje stwierdzenie, że wypowiedzi antropologów, odnoszące się do znaczeń innych społeczności, „powinny być zorientowane na osoby działające”, Clifford Geertz tłumaczył:

Znaczy to, że opisy kultury berberyjskiej, żydowskiej czy francuskiej muszą być wyrażone w kategoriach interpretacji, które, jak sobie wyobrażamy, Berberowie, Żydzi, Francuzi nakładaja na to, co przeżywaja, w formułach, których zwykli używać do określenia tego, co im 
się przydarza. Nie znaczy to jednak, że takie opisy same są opisami berberyjskimi, żydowskimi czy francuskimi, tzn. częścią rzeczywistości, która rzekomo opisują; są one opisami antropologicznymi, a zatem podlegają rozwojowi częścią analizy naukowej. Muszą zostać wyrażone w kategoriach interpretacji, w których osoby określonej klasy podaja swoje doświadczenie, ponieważ, jak głosza, tego są właśnie opisem; sa antropologiczne, ponieważ w rzeczywistości to antropolodzy je wygłaszaja. (Geertz 2003: 45)

Antropolożka Barbara Fatyga w Dzikich znaszej ulicy powiązała istnienie kultury młodzieżowej z trzecim obiegiem kultury, rozwijając zdawkowe konstatacje na ten temat socjologów takich jak Jerzy Wertenstein-Żuławski czy Mirosław Pęczak. Skłaniając się ku ujęciu komunikacyjnemu, Fatyga wskazuje, że refleksja na temat obiegów kultury zakłada zainteresowanie przede wszystkim formami komunikacji, gdzie ,akcentowana jest cyrkulacja treści kulturowych między różnymi grupami odbiorców" (Fatyga 2005: 109). Należy wyróżnić więc typy nadawców i odbiorców, wymagane kompetencje kulturowe, rodzaje komunikatów, kanały komunikacyjne, kody, konteksty sytuacyjne i tak dalej.

Dalej Fatyga stwierdza, że trzeci obieg był odrębny zarówno od oficjalnej kultury wysokiej, jak i oficjalnej kultury masowej, a także od drugiego obiegu. Przyznaje, że głównym elementem scalającym różnorodne prądy i kręgi wewnątrz trzeciego obiegu była negacja obiegów pozostałych. Idzie jednak krok dalej niż wcześniej przywołani autorzy i dostrzega w tej refutacji pewne wspólne cechy, za którymi ukrywają się idee kontrkultury lat sześćdziesiątych i siedemdziesiątych. Z grubsza rzecz biorąc, nurty trzeciego obiegu łączyła krytyka konsumpcjonizmu, komercjalizacji kultury, ideologicznych ingerencji w kulturze. Przejmując od drugiego obiegu konspiracyjny model działalności, uczestnicy trzeciego obiegu odrzucali drugoobiegowe propozycje polityczne i ideologiczne, a własne kanony i hierarchie wartości konstruowali w odniesieniu do wcześniejszych doświadczeń polskiej, a zwłaszcza zachodniej kultury młodzieżowej. Antropolożka podsumowuje:

trzeci obieg - kulturę młodzieżowa - można określić jako względnie autonomiczny podsystem kultury istniejący jako także względnie autonomiczne sieci nadawców i odbiorców, funkcjonujących w specyficznych, najczęściej zmarginalizowanych w stosunku do kultury dominującej, kontekstach. Ma on inaczej niż w dwu poprzednich obiegach ukształtowany sposób cyrkulacji treści (wykorzystujący np. specyficzne kontakty face to face oraz nowoczesną technikę - internet 
i pocztę elektroniczna). Opiera się na odmiennych, w stosunku do dwóch pozostałych obiegów, systemach wartości i ich konkretyzacjach w postaci wzorców i wzorów kulturowych. (tamże: 111-112)

Pomińmy tutaj odniesienie do koncepcji systemów kultury Antoniny Kłoskowskiej, pomińmy też wzmiankę o internecie, który od czasu wydania tej książki wszedł $\mathrm{w}$ stadium Web 2.0 i jest u progu Web 3.0. Najistotniejsze jest dla mnie dostrzeżenie immanentnej struktury trzeciego obiegu, wprawdzie dynamicznej i niedanej w bezpośrednim oglądzie, lecz strukturującej doświadczenia aktorów społecznych, regulującej ich sposoby komunikacji, nadającej sens zespołom czynności, oferującej zestaw idei i ład aksjonormatywny. Wbrew uporczywie powracającym opiniom trzeci obieg nie był przypadkowym zlepkiem krążących w innych obiegach treści, nie był chaotycznym zbiorem heterogenicznych elementów, choć nie był też jednorodny i do homogeniczności nie dążył.

W ujęciu komunikacyjnym pierwszorzędna staje się kwestia języka kultury alternatywnej. To za pomoca języka komunikujemy się, wyrażamy swoje myśli i emocje, porozumiewamy się i spieramy ze sobą. Ważne są użycia języka, style, techniki, obecne nie tylko w eksperymentach poetyckich, lecz i w mowie potocznej. Chodzi o język w rozumieniu antropologicznym, a nie lingwistycznym; konsekwentnie, wykroczenie poza tradycyjną domenę poetyki oznacza analizę praktyk językowych w całym ich bogatym kontekście sytuacyjnym, a nie wyłącznie abstrakcyjnego systemu relacji podobieństw i opozycji, choć zakłada też systematyczne analizy filologiczne. Ponownie skłaniam się ku twierdzeniu Fatygi, że trzeci obieg wykorzystuje obce języki władzy, popkultury, literatury wysokiej, dialekty regionalne, żargony środowiskowe i wyrażenia potoczne, jednak nie powiela ich bezmyślnie, lecz wpisuje we własne konfiguracje, w których poszczególne elementy tracą stare znaczenia a nabierają nowych, zaś całość ma postać modernistycznego kolażu, dla którego równie istotny jak efekt końcowy - a czasami nawet istotniejszy - jest sam proces powstawania, gest kreacji samozwańczego artysty, potwierdzający autonomiczną podmiotowość twórcy. Właśnie dlatego pozostałe po procesie twórczym artefakty raczej dokumentuja go, niż stanowią obiekty do oglądu estetycznego, wykonane z precyzją i semantycznie spójne.

Żadne systemy symboliczne nie są koherentne i logiczne, ponieważ to właśnie wieloznaczność symboli umożliwia rozmaite ich wykładnie, interpretacje i hermeneutyki. Podkreśla to Victor Turner: „Symbole dzięki ich «praktycznym zastosowaniom» zostają oddzielone od abstrakcyjnych 
czy normatywnych «systemów symbolicznych» i połączone z symbolami pochodzącymi z innych systemów lub im przeciwstawione” (Turner 2003: 93).

Badanie samych systemów jest ryzykowną spekulacją, daleką od praktyki życia codziennego, w której to konkretne zastosowania łączą ze soba rozmaite kategorie signifiants i signifiés w niepowtarzalną i procesualną kombinację ściśle przylegająca do doświadczenia posługujących się nimi ludzi. Praktyki komunikacyjne charakterystyczne dla trzeciego obiegu bardzo uwypuklają opresyjność, a jednocześnie pewną fasadowość dominujących uniwersów symbolicznych oraz temporalne przewagi poszczególnych zastosowań, o czym będzie mowa w dalszej części tekstu. Tym bardziej że dominuje w nich analizowane przez Michaiła Bachtina słowo jarmarczne i karnawałowe, a najczęstsze gatunki literackie to te skarnawalizowane: farsa, groteska, persyflaż, pastisz, parodia, trawestacja i im podobne. Negacja powagi oficjalnej normy jest w nich zaledwie punktem wyjścia do rozwinięcia, w charakterystycznej dla siebie ludycznej poetyce, własnej wizji człowieka i świata, filozofii błazeństwa, ustanawiającej na chwilę inny, nieoficjalny model życia i stosunków społecznych. Familiarno-jarmarczny język tej filozofii nie boi się sprzeczności, lubuje się w złym guście, kontrastach, odwróceniach, transgresjach. Familiaryzuje to, co odległe, przenosi tematy z rejestrów wysokich w niskie i na odwrót, skraca dystanse międzyludzkie dzięki wysokiemu kontekstowi dynamiki społecznej. Z upodobaniem gra na polisemii, wieloznacznościach, rymach i asonansach; jak w hermeneutycznym kole interpretacjom nie ma końca, zabawa jako źródło kultury, by nawiązać do tytułu znanej książki Johana Huizingi, nigdy nie wysycha.

W wieloznacznych praktykach komunikacyjnych uczestników trzeciego obiegu szczególnie wyraźnie uwydatnia się dwoista natura komunikacji: może ona być wzajemnym zrozumieniem, ale też ustanowieniem stosunku podległości i dominacji - karnawalizacja wywraca oficjalną hierarchię, lecz bynajmniej nie znosi przemocy maskowanej familiarnością stosunków - najczęściej zaś jest w jakimś stopniu jednym i drugim. Język, którym posługują się członkowie kontrkultur i subkultur, jest w szczególny sposób uwikłany w te dwa wymiary. Starają się oni zazwyczaj stworzyć własny kod komunikacyjny, którym moga porozumiewać się między sobą, a który nie będzie oczywisty dla osób z zewnątrz. Przyczyny i cele są różne, inne w żargonie kibiców, a inne w slangu hipsterów. I tu, i tam pragnieniu jak najskuteczniejszej formy komunikowania wewnątrz własnej grupy 
towarzyszy chęć odróżnienia się od innych grup społecznych (zawodowych, etnicznych, religijnych, młodzieżowych itd.), możemy zatem mówić o dwóch funkcjach: komunikacji i dystynkcji. Dystynkcja zaś, mniej lub bardziej, bywa uwikłana w stosunki podległości i dominacji, to znaczy, może być symbolicznym oporem grupy zdominowanej wobec grupy dominującej albo wyrazem symbolicznej dominacji wzmacniającej dominację społeczną i ekonomiczna. Dychotomia dominacji i zdominowania jest, rzecz jasna, zrelatywizowana i z wyjątkiem grup znajdujących się na samym dole bądź szczycie drabiny hierarchii społecznej akt oporu wobec dominacji jednych jest równocześnie aktem dominacji wobec innych, z niższych klas.

Pisząc o kontrkulturze lat sześćdziesiątych czy późniejszych kulturach alternatywnych, podkreśla się najczęściej aspekt oporu wobec hegemonii kulturowej mieszczaństwa i drobnomieszczaństwa (czynią tak zwłaszcza autorzy zachodni, dla których kulturowa dominacja klas średnich jest czymś o wiele bardziej oczywistym niż w Polsce). To, co z punktu widzenia większości kulturowej jest bezsensowne, chaotyczne, wieloznaczne lub niejasne, stanowić może skutek przemyślanego zabiegu semantycznego, dokonanego przez daną mniejszość, by treści cyrkulujące wśród jej członków nie mogły zostać odczytane przez niewtajemniczonych. Świetnych przykładów takich praktyk, swoistej partyzanckiej walki o znaczenia, dostarcza muzyka rockowa. Amerykański filozof Richard Shusterman podejmuje ten temat, przytaczając znamienne słowa Boba Dylana:

Muzyka rockowa od dawna jest nośnikiem ukrytych znaczeń. Muzyka ta, wytwór niewolnictwa i ucisku kulturowego, potrzebowała skomplikowanych (somatycznych i dyskursywnych) poziomów znaczenia, by wyrażając protest i dumę, wytrącić słuchaczy z niewinnego, bezmyślnego spokoju. Tradycja ta przeszła z kultury czarnej na kulturę młodzieżowa, toteż udzielając wywiadu w roku 1965, Bob Dylan mógł zauważyć: „Gdybym powiedział, o co naprawdę chodzi w naszej muzyce, prawdopodobnie wszystkich nas by przymknęli”. (Shusterman 1998: 239)

Wobec tego właściwe, czyli zmierzajce ku samowiedzy mówiącego odczytanie przekazu $z$ wewnątrz kultury alternatywnej wymaga nie tylko dostrzeżenia go w środku dynamicznej struktury społecznej, ale również próby spojrzenia na świat z perspektywy badanego podmiotu. Innymi słowy, jeśli chcę zrozumieć „ukryte znaczenia”, to, „o co naprawdę chodzi” w kulturze alternatywnej, muszę na pewien czas zrelatywizować własny punkt widzenia i mieć świadomość, że to, co poza kontekstem wydaje się mieć sens literalny, niesie znaczenie metaforyczne, a to, co pozornie zdaje się metafora, 
może być powiedziane całkiem dosłownie. Konieczny jest intelektualny wysiłek zrozumienia tego, co, być może, przekracza ustanowione kulturowo lub prawnie normy, kwestionuje panujący porządek, posługuje się odmienna logiką i funkcjonuje w odmiennym kontekście sytuacyjnym. Poruszam się między Scyllą zniekształcającego wtłoczenia cudzej wypowiedzi we własne ramy poznawcze a Charybda przeoczenia lub zlekceważenia tego, co odbiega od zasad zdrowego rozsądku.

O obiegu alternatywnym pisał między innymi Krzysztof Varga, pisarz w młodości związany z siecią młodzieżowych artzinów. Zauważył on, że oprócz szczególnego typu relacji autorów i czytelników, artziny łączyła też technika wykonania, a także będąca po części jej pochodną - poetyka. Jednak w jej ramach, zdaniem Vargi, nie udało się wypracować własnego języka, czyli „oryginalnego, nowego narzędzia komunikacji wewnątrzgrupowej” (Varga 2002: 15). Częste opinie, według których w praktykach językowych trzeciego obiegu nie było nic nowatorskiego i oryginalnego, a jedynie parodia, żart, ironia lub, co gorsza, całkiem poważne wejście w narzucaną nowomowę, są słuszne tylko wtedy, gdy spogląda się z pozycji dominującej, pozycji bezstronnego z pozoru obserwatora, która okazuje się jednak, para-doksalnie (nawiązuję tutaj do pojęcia doksy Pierre'a Bourdieu) warunkowana przez czynniki tego systemu, którego zakwestionowania się poszukuje, a po znalezieniu go - kwestionuje. Mimo deklarowanej postawy krytycznej Varga pozostaje pod wpływem romantycznej ideologii twórczości i romantycznego wyobrażenia twórcy. Innymi słowy, zamiast w hermeneutycznym badacz znajduje się w błędnym kole, ponieważ praktyki podważające system rozpatruje w kategoriach przez ten system ukutych. Efektem takiego rozumowania musi być potwierdzenie przyjętych uprzednio założeń. Propozycję ucieczki z tego błędnego koła oferuje Michel de Certeau. W ksiazżce Wynaleźć codzienność przenikliwie zauważa on, że:

Racjonalnemu, ekspansjonistycznemu, centralnemu, spektakularnemu oraz hałaśliwemu wytwarzaniu jest przeciwstawiona produkcja zupełnie innego rodzaju, określana jako konsumpcja charakteryzująca się podstępami, rozpadem zależnym od sposobności, kłusowaniem, skrytością, nieustannym szemraniem, czyli, w sumie, niby-niewidzialnością, gdyż nie ujawnia się ona poprzez własne produkty (gdzie znalazłaby dla nich miejsce?), ale przez sztukę używania produktów jej narzuconych. (de Certeau 2008: 32)

$\mathrm{Na}$ gruncie trzecioobiegowych praktyk językowych uważam zatem, że produkcji nowomowy i popkulturowego bełkotu przeciwstawiona jest nie dokonywana w analogiczny sposób produkcja konkurencyjnej mowy, 
lecz produkcja-konsumpcja, przebiegłe i przewrotne wykorzystywanie zastanych elementów (zwrotów, wyrażeń, fraz, epitetów, formuł i tak dalej), za pomoca których w ukryciu przed okiem smoka (Dunin-Wąsowicz 2005) jego terytorium przekształca się w incydentalna przestrzeń wolności. Akt mówienia nie jest jedynie realizacją reguł zapisanych w strukturze języka. Polega on na działaniu, za każdym razem innym, pragmatycznie wykorzystującym język przez osoby mówiące, znajdujące się w nieuchwytnej teraźniejszości tu i teraz, same będące tylko miejscem spotkania szeregu relacji i oddziaływań. Chodzi więc o rodzaj partyzanckiej walki o znaczenia, toczącej się wewnątrz systemu, a nie batalii i bitew regularnych armii. Skuteczność tkwi w zmianie skali. W odniesieniu do praktyk językowych na tekstach kultury elitarnej de Certeau pisał:

Narzucony zasób wiedzy i symboliki jest przedmiotem manipulacji dokonywanych przez użytkowników niebędących ich wytwórcami. Język wytworzony przez jakąś kategorię społeczną ma władzę rozszerzania swych podbojów na rozległe otaczające go obszary, «pustynie», na których nic podobnie wyrażonego wydaje się nie istnieć, ale gdzie wpada on w pułapkę asymilacji, zastawionej przez gaszcz procedur powodujących, że jego własne zwycięstwa skrywają go przed okupantem. Niezależnie od tego, jak spektakularna jest jego przewaga, może się ona okazać złudzeniem, jeśli będzie służyć wyłącznie jako tło uporczywych, sprytnych, codziennych praktyk, które ją wykorzystują. To, co nazywamy „popularyzacja” albo „degradacja” jakiejś kultury, byłoby zatem jakimś karykaturalnym i niecałkowitym przejawem rewanżu, jaki taktyki użycia biorą nad dominującą władzą produkcji. (tamże: 33)

Pozwoliłem sobie na ten przydługi cytat, ponieważ trafia on w sedno moich rozważań. Praktyki językowe trzeciego obiegu rozpatruję właśnie jako elastyczne, zdolne do natychmiastowej rekonstrukcji i wykorzystujące nadarzające się akurat sposobności realizacji taktyk, efemeryczne, niemożliwe do przyszpilenia i systemowej regulacji. Wprowadzone przez de Certeau rozróżnienie na strategie i taktyki przyjmuje jako fundamentalne dla eksploracji interesującego mnie zagadnienia, przy czym rozróżnienie to rozumiem następująco. Strategie wiążą się z pozycją dominującą w porządku społecznym, z wyznaczaniem centrum i peryferiów, narzucaniem własnej hegemonii kulturowej, aplikowanej w formie przemocy symbolicznej lub strukturalnej. Stosowanie strategii wymaga zawsze jakiegoś podmiotu władzy - choćby było to, po foucaultowsku, jedynie miejsce w dyskursie - i przestrzeni realizacji. Strategie wyznaczaja pola gry i w nich operuja. Ich siła jest zatem ich potencjalną słabością: im głębiej przenikają 
społeczeństwo naczynia kapilarne władzy, tym bardziej wymyślne i zróżnicowane stają się sposoby odwracania ich na swoją korzyść, oszukiwania i symulacji, którymi posługuja się zawieszone w sieci znaczeń jednostki. Tymi metodami są właśnie taktyki; użycia narzuconych produktów, poruszanie się w obcej przestrzeni, wykonywanie zewnętrznych zadań i poleceń mają charakter taktyczny. Można by powiedzieć, że taktyka jest domeną słabego, ale pojęcie domeny implikuje przestrzeń, terytorium, pole, w którym się działa, tymczasem słaby jest wrzucony w pole Innego, zmuszony do przemykania i skrywania bez możliwości okopania się we własnym polu, zapanowania nad swoim terytorium. Stąd częsta u de Certeau metafora kłusownictwa jako praktyk taktycznych. Taktyki, pozbawione oparcia w miejscach, instytucjach, dyskursach i produkcji, moga jednak chwilowo je przechwytywać, zagarniać, blefować wobec nich. Są zespołem trików przypadkowego gracza zmuszonego grać w nielubiana grę i w dodatku obcą talią kart.

Nie znaczy to, że nie chcę zauważyć zależności taktyk od dominujących form językowych i sposobów komunikacji, która to zależność sama ma charakter strukturalny. Konstruktywizm społeczny, proponowany w krytycznej socjologii kultury Pierre'a Bourdieu, stanowi, w mojej opinii, niezbywalna podstawę wszelkich badań procesów zachodzących w polu sztuki, gdzie w grę wchodzą różne kombinacje różnych rodzajów kapitału, etosy klasowe i habitusy. Podobnie za niezwykle inspirujące uważam foucaultowskie pojęcie ruchu kontrprowadzenia, wyprowadzane $z$ analizy genealogicznej średniowiecznych ruchów oporu, buntów, herezji i odstępstw religijnych, sprzeciwiających się kościelnej władzy pastoralnej (Foucault 2010: 216). W odniesieniu do europejskiej nowoczesności Michel Foucault wyróżniał trzy eschatologie współczesnych ruchów kontrprowadzenia, oponujące wobec nadrzędności instancji państwa: społeczeństwa obywatelskiego, radykalnej, anarchicznej wolności i wreszcie samostanowiącego, mającego własny charakter narodu (tamże: 359-360). Wszystkie one dają się zauważyć w rozmaitych układach, w ruchach oporu kultury alternatywnej. Jednak moją intencja jest spojrzenie z innej perspektywy, odsłaniającej przeoczane dotychczas ważkie szczegóły.

W tym celu Jakobsonowski telegraficzny model komunikacji, jakim posługiwała się Fatyga, muszę zamienić na antropologiczny model orkiestralny (Winkin 2003), w którym różne rodzaje komunikatów o rozmaitych kodach są równocześnie wieloma kanałami emitowane przez jednostki wymiennie przyjmujące role nadawców i odbiorców. Ten typ bliższy jest codziennej rzeczywistości kulturowej, ponieważ odnosi się do sytuacji 
społecznej, a nie mechanicznego przesyłu danych. Znakomicie oddaje też specyfikę komunikacji trzeciego obiegu. Stąd wynika zainteresowanie praktykami nie tylko językowymi, ale też innymi sposobami komunikacji, sztukami działania, interakcjami symbolicznymi i wszelkiego rodzaju kłusownictwem w polu wyznaczanym przez dominujące klasy i dyskursy władzy. Próba zrozumienia kruchej i kapryśnej logiki codzienności wymusza umieszczenie własnej pracy intelektualnej o charakterze analitycznym na tej samej płaszczyźnie, co inne praktyki życia codziennego. Praktyk kulturowych, na co wskazywal już Bourdieu, nie da się wyizolować ani uogólnić, są one sposobem doświadczania, by nie powiedzieć górnolotnie - istnienia. W tej perspektywie tło staje się bohaterem, osacza to, czemu miało asystować, przenika do jego środka, z wypełnienia pustej przestrzeni przechodzi transformację w aktywnego gracza. Rozdzielanie składających się na sytuację komunikacyjną elementów (mowa, kinezyka, proksemika i tak dalej) powodowałoby utratę ich sensu tkwiącego w synergii. Dlatego poziom praktyk językowych wymaga rozszerzenia i uzupełnienia o wszelkie praktyki komunikacyjne czy po prostu kulturowe, a następnie rekonstrukcji na tej podstawie taktyk kłusowników trzeciego obiegu.

Nie chodzi tutaj o tworzenie nowych typologii - tych powstało już na gruncie różnych dziedzin wiedzy dostatecznie dużo, choć mają rozmaita wartość. Celem winno być raczej wyznaczenie podstawowych tendencji, naczelnych osi, które pozwalają sprawnie poruszać się po badanym terytorium. Można by je przykładać i odsuwać, zorientowawszy się w konfiguracji zazębiających się procesów. Ta taktyka jest sama w sobie rodzajem metodologicznego kłusownictwa, zakłada wszak zbliżanie się do majaczącego na horyzoncie, a być może zgoła fantazmatycznego obiektu, i dystansowanie się wobec niego w chwili, gdy jest już na wyciagnięcie ręki. Konsekwentna w swej niekonsekwencji, problematyzująca własny status, przypomina metodę paranoiczno-krytyczną Salwadora Dalego. Zagłębienie się w sobie, w swoich (lub też medycznie zdiagnozowanych paranoików) pragnieniach, popędach, fiksacjach i marzeniach sennych - w całym tym najbardziej subiektywnym, a przez to społecznym świecie - Dali konfrontował z chłodnym, krytycznym namysłem umysłu świadomego swojej cielesności. Praca antropologa w proponowanym tutaj podejściu jest podobna, zakłada bowiem tym większy dystans obiektywizujący, im bardziej znajomy i swojski jest jej przedmiot. Jedna i druga sa formami hermeneutyki podejrzliwości, zaprzeczeniem introspekcji.

Paranoja krytyczna jako metoda przeniesiona $z$ historii idei artystycznych na grunt nauk społecznych nie jest bynajmniej efektywnym 
posunięciem retorycznym w zakończeniu artykułu. Metoda paranoiczno-krytyczna, a szerzej - surrealizm - jest bowiem właśnie tym nurtem w sztuce, który z nauk społecznych przyswoił sobie wyjątkowo wiele, w zamian dostarczając im inspiracji, krytyki, a także - o czym właśnie mowa refleksji metodologicznej. Zachwycając się dziś surrealistycznymi obrazami i poematami, zapomina się, że sztuce surrealiści wyznaczali rolę służebną wobec ich głównego celu, poznania człowieka; twórczość miała być droga do tego poznania, podobnie jak marzenie senne - do penetracji nieświadomości. Chłonęli ówczesną atmosferę intelektualną, jak chociażby odkrycia fizyki kwantowej czy logiki wielowartościowej, zakładali własne jednostki badawcze (Biuro Badań Surrealistycznych, kierowane przez Antonina Artauda), dokonali jednej z pierwszych syntez marksizmu i psychoanalizy. O surrealistycznych reinterpretacjach materializmu dialektycznego i psychologii głębi pisano wiele, nie rozwijam więc tego wątku. Bardziej interesuje mnie związek surrealizmu z etnologia i antropologia kulturowa, rozwijający się szczególnie intensywnie w latach czterdziestych i pięćdziesiątych, w związku z zainteresowaniem grupy André Bretona mitami, przesądami, wyobrażeniami zbiorowymi i rytuałami. Ci z surrealistów, którzy lata czterdzieste przeżyli na emigracji w Ameryce, spędzali całe dnie w Museum of the American Indian i wśród ulicznych handlarzy, niemal nałogowo kupując najrozmaitsze przedmioty sztuki prymitywnej z Ameryki, Japonii, Oceanii. Szybko stali się koneserami tej sztuki, posiadaczami prywatnych kolekcji zagadkowych obiektów znalezionych. Kolekcjonując je i prezentując na wystawach, nadawali im status dzieł sztuki, a nie artefaktów etnograficznych, o czym pisze James Clifford we wspomnianych Kłopotach z kultura (Clifford 2000: 262). W wydawanym w Nowym Jorku w latach 1942-1944 surrealistycznym piśmie „V V V” pojawiały się eseje inspirowane sztuka prymitywną, a wśród autorów znaleźli się zaprzyjaźnieni z grupa Bretona Lévi-Strauss i Roger Caillois.

Natężenie zainteresowania etnologia $\mathrm{i}$ antropologia kulturową nie wpłynęło jednak na głębsze przyswojenie sobie przez artystów dorobku tych nauk, szczególnie w kontekście równoległych poszukiwań okultystycznych. Antropologia, praktykowana przez surrealistów, z filozofii, która wybrała się w podróż, przeobraziła się w filozofię ucieczki, by znów odwołać się do Mencwela. Dlatego inspirujących współcześnie punktów styku między surrealizmem a antropologia należy szukać wcześniej, w czasach dwudziestolecia, gdy grupa nie ruszała się zbyt często z Paryża. Niechęć surrealistów do podróży była wręcz przedmiotem anegdot - bodaj tylko raz kilkoro z artystów przyłączyło się do wyprawy etnologicznej 
po Afryce. Byli raczej bohaterami salonowych skandali i kawiarnianych awantur. Nie opuszczając Paryża, inności poszukiwali wokół siebie - stąd zainteresowania twórczością dzieci i umysłowo chorych, stąd stany deliryczne i dezautomatyzujące percepcję „wyrozumowane rozprężenie wszystkich zmysłów", wedle słów Artura Rimbauda, uwielbianego przez surrealistów. Przyniosło to efekt w postaci takich książek, jak Wieśniak paryski Louisa Aragona, którego bohater porusza się po omacku w onirycznym mieście, pełnym tajemniczych spotkań i nagłych hierofanii. Poetyckie udziwnienia codziennej rzeczywistości miały przy tym służyć nie tyle jej estetyzacji, ile wykroczeniu poza kulturowo narzucane schematy poznawcze. Precyzyjną konceptualizację tego zamiaru przynosi właśnie metoda paranoiczno-krytyczna Dalego, która według definicji jej twórcy jest „spontaniczną metoda poznania irracjonalnego, oparta na krytycznej i systematycznej obiektywizacji delirycznych skojarzeń i interpretacji”. To już otwarcie na inność, a nie demiurgiczne jej kreowanie - przynajmniej w warstwie deklaracji, ponieważ od twórczości malarskiej i postawy życiowej Dalego celowo abstrahuję. Sęk w tym, że badając kulturę własna, stawiamy się w paradoksalnej sytuacji wieśniaka paryskiego - wieśniaka mieszkającego w jednej z największych światowych metropolii.

Ostatecznie porównanie antropologii kulturowej i metody paranoiczno-krytycznej - tę druga już Breton widział jako wykraczająca poza sferę twórczości procedurę poznawania i interpretacji - znajduje uzasadnienie w twórczości Geertza. Znane sa jego słynne słowa: „ "Co etnograf robi?» - on pisze" (Geertz 2003: 49). A tym, co etnograf pisze, jest esej, będący „naturalnym gatunkiem do przedstawiania zarówno interpretacji kulturowych, jak i wspierających je teorii" (tamże: 54), nie zaś charakterystyczne dla nauk ścisłych rozprawy i traktaty. Geertzowska antropologia opiera się na rozmowie, której celem jest poznanie i zrozumienie Innego, zarówno tego żyjącego na egzotycznych wyspach, jak i tego, którego każdy ukrywa w Sobie, jak rysę na lśniącej powierzchni lustra. Pisanie antropologicznego eseju, podobnie jak malowanie surrealistycznego obrazu, jest rodzajem sztuki mającej swoje zadania i metody. Po drugie, pisanie nigdy nie odbywa się samo dla siebie - ono zawsze dzieje się dla Innego, choćby tym Innym było ja osoby piszącej. Z pewnością antropologię określa jej specyficzny zawodowy habitus, wdrażany i podtrzymywany w akademiach i instytutach badawczych, na konferencjach i wyjazdach w teren. Habitus ten wyznacza pole percepcji badacza oraz ustawia ostrość jego spojrzenia na tych, a nie innych obiektach. Etnograf, który pisze, poddany swemu habitusowi, nawiązuje jednocześnie pewną nieformalną umowę społeczną ze swoim 
czytelnikiem, która przez analogię wobec paktu autobiograficznego Philippe’a Lejeune'a (Lejeune 2001) moglibyśmy nazwać paktem etnograficznym. Zasada naczelną byłoby w tym wypadku opisanie danej kultury za pomoca jej kategorii interpretacji, lecz bez popadania w błąd going native, czyli przyjmowania jej tożsamości. Oba pakty są prawdopodobnie niemożliwe do wypełnienia. Autobiografia opiera się na wierze w jednolita, spójną tożsamość, możliwą do poznania i zrozumienia, podczas gdy zawsze w grę wchodzą rozmaite, konkurencyjne wobec siebie ja. Podobnie etnografia często upraszcza i petryfikuje kultury w pewne typy i modele, przedstawia je w sposób wyrywkowy, jednowymiarowy lub powierzchowny. Umowa wykonania tego, co być może niewykonalne, nie przestaje jednak obowiązywać. Metoda paranoiczno-krytyczna jako z założenia prowadząca do niejednoznacznego, wielowymiarowego i zdynamizowanego obrazu może stanowić wzór konsekwentnie niekonsekwentnego postępowania, które w celu wypełnienia umowy dopuszcza jej naruszanie.

\section{Bibliografia:}

/// Bińczycki J. 2010. Nielegalne przestrzenie kultury, [w:] Kultura niez̧ależna w Polsce 1989-2009, Korporacja Ha!art, Kraków.

/// Certeau M de. 2008. Wynaleźć codzৃienność. Sztuki dziatania, tłum. K. Thiel-Jańczuk, Wydawnictwo Uniwersytetu Jagiellońskiego, Kraków.

/// Clifford J. 2000. Klopoty z. kultura. Dwudziestowieczna etnografia, literatura i sztuka, tłum. E. Dżurak i inni, Wydawnictwo KR, Warszawa.

/// Dunin-Wąsowicz P. 2005. Oko smoka. Literatura tzw. pokolenia „,brulionu” wobec rzeczymistości III RP, Lampa i Iskra Boża, Warszawa.

/// Fatyga B. 2005. Dricy z naszej ulicy. Antropologia kultury mtodzieżowej, Ośrodek Badań Młodzieży, Instytut Stosowanych Nauk Społecznych UW, Warszawa.

/// Foucault M. 2010. Bezpieczeństwo, terytorium, populacja, tłum. M. Herer, Wydawnictwo Naukowe PWN, Warszawa.

/// Geertz C. 2003. Opis gesty - w strone interpretatywnej teorii kultury, tłum. S. Sikora, [w:] Badanie kultury. Elementy teorii antropologicznej, red. M. Kempny, E. Nowicka, Wydawnictwo Naukowe PWN, Warszawa, s. 35-58.

/// Hopfinger M. 2010. Literatura i media. Po 1989, Oficyna Naukowa, Warszawa. 
/// Janicka K. 1985. Surrealizm, Wydawnictwa Artystyczne i Filmowe., Warszawa.

/// Lejeune P. 2001. Wariacje na temat pewnego paktu. O autobiografii, tłum. W. Grajewski, S. Jaworski, A. Labuda, R. Lubas-Bartoszyńska., Towarzystwo Autorów i Wydawców Prac Naukowych UNIVERSITAS, Kraków.

/// Lesiakowski K, Perzyna P, Toborek T. 2004. Jarocin w obiektymie bezpieki, Instytut Pamięci Narodowej, Komisja Ścigania Zbrodni przeciwko Narodowi Polskiemu, Warszawa.

/// Mencwel A. 2006. Wyobraźnia antropologicz̨na, Wydawnictwa Uniwersytetu Warszawskiego, Warszawa.

/// Pęczak M. 1992. Maty stownik subkultur mtodżieżowych, Wydawnictwo Naukowe Semper, Warszawa.

/// PL. 1988. Anielska alternatywa, „Kultura Niezależna” 1988, nr 38, s. 84.

/// Shusterman R. 1998. Estetyka pragmatyczna: syme piekno i refleksja nad sztuka, tłum. A. Chmielewski, E. Ignaczak, L. Koczanowicz, L. Nysler, A. Orzechowski, Wydawnictwo Uniwersytetu Wrocławskiego, Wrocław.

/// Turne, V. 2003. Badania nad symbolami, tłum. E. Klekot, [w:] Badanie kultury. Elementy teorii antropologicznej, red. M. Kempny, E. Nowicka, Wydawnictwo Naukowe PWN, Warszawa, s. 89-105.

/// Varga K. 2002. Tržecia droga, [w:] Xerofeeria 2.0 antologia artzinón, red. P. Dunin-Wąsowicz, Lampa i Iskra Boża, Warszawa, s. 4-18.

/// Wertenstein-Żuławski J. 1991. Træy obiegi - tray kultury. Struktura spoteczna i komunikowanie w dzisiejszej Polsce, [w:] Thumom i wyzwanie. Pamietnik VIII Ogólnopolskiego Zjazdu Socjologičnego Toruń, 19-22.09.1990, red. A. Sułek i W. Wincławski, Wydawnictwo Adam Marszałek, Warszawa-Toruń.

/// Winkin Y. 2003. Telegraf i orkiestra, [w:] Antropologia stowa. Zagadnienia i mybór tekstów, red. G. Godlewski, A. Mencwel, R. Sulima, Wydawnictwa Uniwersytetu Warszawskiego, Warszawa. 


\section{/// Abstrakt}

Artykuł dotyczy problemów związanych z antropologicznym badaniem kultury badacza. Problem podejmowany jest na przykładzie badania kultury alternatywnej przez osobę z tą kultura związana. Zostaje rozwinięte ujęcie komunikacyjne ze szczególnym uwzględnieniem języka i praktyk komunikacyjnych.

Słowa kluczowe:

kultura alternatywna, antropologia, surrealizm, komunikacja

\section{/// Abstract}

The article concerns a few major ethical and cognitive problems with anthropological researches of researcher's culture. Exemplification of this issue is scientific research of alternative culture or counter culture done from inside of this type of culture. The author coping with this problem applies communication perspective with special emphasize on language and communication practics.

Keywords:

alternative culture, anthropology, surrealism, communication 